This is an electronic reprint of the original article. This reprint may differ from the original in pagination and typographic detail.

Author(s): Nokkala, Terhi; Bacevic, Jana

Title: University Autonomy, Agenda Setting and the Construction of Agency : the case of the European University Association in the European Higher Education Area

Year: $\quad 2014$

Version:

Please cite the original version:

Nokkala, T., \& Bacevic, J. (2014). University Autonomy, Agenda Setting and the Construction of Agency : the case of the European University Association in the European Higher Education Area. European Educational Research Journal, 13(6), 699714. https://doi.org/10.2304/eerj.2014.13.6.699

All material supplied via JYX is protected by copyright and other intellectual property rights, and duplication or sale of all or part of any of the repository collections is not permitted, except that material may be duplicated by you for your research use or educational purposes in electronic or print form. You must obtain permission for any other use. Electronic or print copies may not be offered, whether for sale or otherwise to anyone who is not an authorised user. 
University autonomy, agenda setting and the construction of agency -

The case of European University Association in the European Higher Education Area

Final draft 10.6.2014

NOTE 19.12.2014: The article has been published at

www.wwwords.eu/eerj/content/pdfs/13/issue13_6.asp

\section{Authors}

Dr Terhi Nokkala

Research fellow

Finnish Institute for Educational Research

P.O.Box 35

40014 University of Jyväskylä

Finland

Terhi.nokkala@jyu.fi (corresponding author)

Dr Terhi Nokkala is a Senior Researcher at the Finnish Institute for Educational Research (FIER), University of Jyväskylä. Her research focuses on the interplay between higher education policy, technological developments, organisational parameters and networks, and individual experiences in various aspects of higher education, with specific interest in internationalisation, research collaboration and university autonomy. She has previously worked at the University of Tampere, Finland, and University of Surrey, UK.

Dr Jana Bacevic

Postdoctoral researcher

Department of Education

University of Aarhus

Tuborgvej 164

2400 København NV

Denmark

jaba@dpu.dk 
Dr Jana Bacevic is a postdoctoral researcher at the Department of Education (DPU), University of Aarhus, Denmark, and Visiting Fellow at the Graduate School of Education, University of Bristol, UK, working on the EU FP7 Marie Curie ITN Universities in Knowledge Economies (UNIKE). Her research deals with the social roles of universities, intellectuals, and "knowledge" in the society, the political and policy processes related to the relationship between universities and societies, and the concept of agency in academia. She has previously taught at the Central European University in Budapest, Hungary.

\title{
University autonomy, agenda setting and the construction of agency - The case of European University Association in the European Higher Education Area
}

\begin{abstract}
This article analyses the ways in which a policy actor constructs its agency through the production of knowledge. Taking the example of concept of "autonomy" as constructed in the discourse of the European University Association (EUA), the article draws on the theory of discursive framing and agenda setting as well as Meyer and Jepperson's (2000) heuristic of agentic actors to show how the practice of knowledge production can shape the European higher education policy. The paper offers a contribution to the debate aiming to develop a more critical perspective on the development of the European Higher Education Area, which sees the process as constituted through the activities of and negotiations between different political actors.
\end{abstract}

\section{Introduction}

The Bologna Process represents a unique, unparalleled development in the construction of European higher education policy. Formally initiated in 1999 by the European ministers responsible for higher education, it is an intergovernmental policy process aimed at establishing the European Higher Education Area. The focal goal of the Process is to increase the competitiveness and attractiveness of the European higher education by promoting structural and procedural convergence in national higher education. With 47 full and eight consultative members, the Bologna Process influences national policy making in Europe and beyond (Ravinet 2008; Robertson \& Keeling 2008; Voegtle et al 2011). The scope and size of the transformations that are connected with the Bologna Process, however, sometimes lead to it being considered the chief, if not sole, frame of higher education dynamics in Europe. This type of discourse can obscure the fact that what is perceived as the "Bologna Process" is, in fact, an arena in which the ideas and agendas of different actors meet, interact, and clash, thus engage in a struggle for "monopoly" over meaning-making (e.g. Corbett, 2005; Wright, 1998). This perspective leads to the necessity to consider in more depth the role of different actors, as well as of agency, in the transformation of European higher education. 
A substantial body of scholarly work has been devoted to the institutionalisation of interest organisations in the European policy space, most notably the European Union (Greenwood 2007a, 2007b). Similarly, the implementation of the Bologna Process on national and institutional levels has received plenty of attention. There is, however, significantly less research on the roles of different actors in the processes of agenda setting of the European Higher Education Area although the process itself bears similarities with the emergence of agendas in the European multilevel governance described by Greenwood (2007a, 2007b). Recent exceptions include for example Elken and Vukasovic (2014), who chart the inclusion of the different collective actors to the Bologna Process. Similarly, Ravinet (2008) notes the early role of Association of European Universities (CRE) and the Austrian Ministry of Education, as well as the influence of the Sorbonne Follow-up Group established in the aftermath of the signing of the Sorbonne declaration in 1998. Keeling (2006) and Beerkens (2008) show the influence of the European Commission in aligning the discourses of the Bologna process with those of the EU-led initiative of the European Research Area; whilst Klemenčič (2011) addresses the role of the European Students' Union. One of the arguably most prominent actors and its role in the Bologna Process, however, is still largely absent from these analyses.

This actor is the European University Association (EUA). EUA was established in 2001 in Salamanca, Spain, as an outcome of the merger between Association of European Universities (CRE) and the Confederation of European Union Rectors' Conferences (EURec). The EUA, thus, was "born" shortly after the Bologna Process; the merger of two organizations was a result of the desire of the organisations to provide one voice for the university sector in Europe in terms of the changing European higher education policies (EUA 2000). Currently, EUA is - together with the European Association of Institutions in Higher Education (EURASHE), the European Network for Quality Assurance in Higher Education (ENQA) and the European Students' Union (ESU) - part of the informal but influential "E4" group of consultative members to the Bologna Process ${ }^{1}$. EUA also holds a permanent membership in the most important follow-up body of the Process between the ministerial meetings, Bologna Follow-up Group (BFUG) and its board (BFUG-Board) (www.ehea.info).

EUA's original mission was to represent European Universities in the Bologna Process. Currently, its membership base lists over 850 institutions from 47 countries. However, over the course of thirteen years of its existence, the role of the association has expanded beyond pure representation. On the one hand, EUA provides a variety of services for the members, among which probably the most familiar is the Institutional Evaluation Programme - a sort of customized, on-demand evaluation exercise in which EUA experts visit an institution and assess it according to number of criteria, producing a report and set

\footnotetext{
${ }^{1}$ As Elken and Vukasovic (2014) point out, the consultative members exert significant influence in the Bologna Process, and thus the distinction between the full members and consultative members in the Bologna Process does not present the full picture.
} 
of recommendations. Other services include the development of doctoral education, consultancy, and networking for and between members. On the other hand, in addition to the "service" dimension, EUA has evolved into a veritable knowledge-producing powerhouse.

To begin with, EUA has been responsible for producing the most important stocktaking document of the Bologna Process, known as the Trends report (Haug and Kirstein 1999; Haug and Tauch 2001; Reichert and Tauch 2003, 2005; Crosier et al. 2007; Sursock and Smidt 2010). Trends have been used to summarize the "progress" of individual countries in the implementation of the various action lines of the Bologna Process, and thus also as an important measure of the overall "degree" of the implementation of the process in Europe. But its activity in the field of knowledge production goes beyond this. In the past ten years, EUA has authored expert analyses on a number of topics related to key policy areas in European higher education, including autonomy, system diversification, financing, quality assurance, internationalization, etc. (e.g. Estermann and Nokkala 2009, Reichert 2009, Loukkola and Zhang 2010, Estermann and Bennetot Pruvot 2011, Estermann et all 2011, Sursock 2011 etc.). These analyses have become authoritative sources shaping the thinking on European higher education.

Of course, there is hardly anything strange about a representative association producing knowledge related to its area of interest; political parties, labour unions, and civil society organisations routinely conduct or commission surveys in order to inform their policies. After all, with the transition to "Mode 2" and further, to "Mode 3", knowledge production, knowledge has become disembedded from universities and particular disciplines, and increasingly applied and "problem-oriented" (cf. Nowotny et al, 2001; Carayannis and Campbell, 2009). However, EUA research is noteworthy in the sense in which it produces knowledge not about the "outside world", but primarily about its own constituency: the universities themselves. EUA knowledge production, thus, contributes to the construction of identities and agency of its member institutions. In other words, the reports produced by EUA do not only reflect the "reality" of the "European higher education area"; they inevitably also construct it.

\section{Problem definition, theoretical and methodological approach}

The starting question of this paper is how EUA's knowledge production influences European higher education policy. More specifically, it aims to provide a critical assessment of the ways in which knowledge produced by EUA defines and limits the agency both of its member institutions and of EUA itself. It relies on the scholarship of the interaction between knowledge production and power relationships that recognizes that knowledge claims are never "objective" or isolated from their social contexts, but need to be defined in relation to other objects or actors (Foucault 1980; Kogan, 2007; Kuhn, 1962). In this sense, we argue that understanding the role of EUA in the Bologna Process requires looking at the ways in 
which the practice of knowledge production constructs and shapes the agency of the EUA as well as that of its member organisations.

The paper focuses on the EUA texts that deal with the concept of university autonomy. Early on in the Bologna Process, autonomy became a sort of "signature concept" of EUA and started figuring very prominently in its policy documents. The struggle to acquire "monopoly of meaning" (cf. Wright 1998) over the concept of autonomy can thus be seen as one of the key elements in the construction of EUA's agency in the European Higher Education Area. While autonomy is a comprehensively studied phenomenon, there is little consensus on what it actually represents. Over the years, the definitions and emphasis have shifted from the concept of autonomy as the guardian of academic freedom, which was its primary definition in the period between 1960s and 1980s, to an instrumental concept focusing on the relationship of governance and authority between the state and the higher education institution (Zgaga 2010). The recent European policy discussion has converged around the freedom of the university to determine its management and finances in addition to the more traditional notions of freedom of education and research, whilst academic freedom has in places been restricted as a consequence of increased institutional autonomy and the new steering and accountability mechanisms for higher education (Nokkala \& Bladh 2014). Autonomy can thus legitimately be seen as a semantic or discursive space for the encounter of different agendas and ideologies, simultaneously constituted by and constitutive of various institutional and political structures.

Looking at the evolution of the concept of autonomy in EUA's policy documents, thus, can enable us to understand the shifts in the positioning of this actor in the European higher education policy space. As Sell and Prakash argue: "One of the most important activities of any campaign is agenda setting - generating issues by disseminating information and providing a normative frame to interpret it. The agenda setting process is shaped by how various perspectives are presented in relation to dominant policy concerns. Normative frames help to translate information into knowledge" (2004, p. 157). Agenda setting, in itself, is based on a process of framing (Snow et al 1986; Benford and Snow 2000) whereby social actors produce frames that legitimate their goals, tactics and participation in the European higher education policy making. These frames are discursive in nature. Discourses in policy texts construct policy problems in particular ways, argue for the necessity and appropriateness of reform, and privilege particular solutions. Thus they legitimate and explain policy change (Newman 2001, Schmidt 2002). Discourses are both constitutive of the agenda setting and problem definition in policy making (cf. Hoppe 1993), and mutually constitutive of the social reality in which policymaking takes place. They support and reproduce, but may also undermine and change, institutions and power relations (Parker 1992, p. 15-20). Discourses form a social reality in which particular courses of action appear as the only legitimate and rational ones (Jessop 2004). 
Yet policy texts are also aimed at particular audiences: members, collaborators and stakeholders. As such, actors use discourses to provide leverage for a better position or for more benefits for themselves. As strategic texts, aimed at framing the policy debate in the European arena, the selection of texts analysed here carry framing tasks (Shin and Tsutsui 2007, p. 320; cf. Snow et al 1986; Benford and Snow 2000). Firstly, through diagnostic framing they highlight the problem which needs to be solved. Secondly, through prognostic framing they propose the solution to the identified problem. Finally, through motivational framing, they appeal to the constituents and stakeholders convincing them about the efficacy of each actor or process in addressing the problem with the proposed solution.

The objective of the analysis presented here is to move beyond the analysis of "discourse for discourse's sake", and instead look at what discourse does or, at the very least, how it aims to enable different social actors to do things. Policy discourses typically use a set of linguistic tools for meaning-making, including transitivity to make connections between actions and objects, active or passive tone to highlight or obscure the agency of various actors, and different modalities to construct truth claims (see e.g. Jørgensen \& Phillips 2002, pp. 83-84.) We have approached the selected policy documents by analysing the linguistic features that make up the fabric of the discourse. First, the passages that mention university autonomy have been identified from all documents. Those passages that mention autonomy only very superficially and in passing without raising it as an object of policy claim, have been noted but left out of more thorough analysis. The remaining texts have been analysed paying attention to the linguistic features that, for example, assign tasks, rights or obligations to particular actors, or describe the conditions in which particular policy goals can be achieved. We have focused on the elements or characteristics of autonomy (e.g. autonomy as given by the state or taken by the universities), the roles or tasks assigned to autonomy (e.g. autonomy enables competitiveness) and the other concepts it is linked to in the texts (e.g. autonomy and accountability or autonomy and diversity). The conditions of autonomy have been noted, such as the notion that without adequate funding there is no true autonomy and the notion that in exchange for autonomy universities must be accountable to the society as a whole.

In the analysis of how the concept of autonomy is used to position EUA as an actor, both in itself and vis-à-vis other actors in the European Higher Education Area, we rely on Meyer and Jepperson's (2000) typology of the properties of agentic actors. The first property is the capacity to define agency for themselves; in this context, the discursive construction of agency is fundamentally intertwined with the construction of the identity of the institution/organisation itself. The second property is to define agency for others; in the case of EUA, the discursive construction of agency is fundamentally intertwined with its role in representing its members, i.e. European universities. The final property is to define agency as an exercise of a moral or ethical imperative; in this sense, as we will show, the discursive construction of autonomy is related to the conceptual monopoly over the meanings and functions of the Bologna Process itself. 
The paper will proceed to analyse the EUA texts in the context of these frameworks. The analysis of these texts relies on the discourse-historical approach and conceptual history from the family of critical discourse analysis (CDA) (Wodak 2001, Wodak 2008, Krzyzanowski \& Wodak 2011, Krzyzanowski 2010). The data used in the analysis comprises firstly the policy texts produced by the European University Association, namely the Declarations (EUA $2001,2003,2005,2007,2009,2011$ ) of the EUA biennial convention, which represents the highest level of formality amongst EUA events and, consequently, documents. The analysis also covers 48 other EUA policy documents and statements from 2003-2012 available on the EUA website (www.eua.be), of which 19 contain significant excerpts on autonomy whilst in 29 autonomy is only mentioned in a tokenistic way or as a passing description of EUA's work on university autonomy. Finally, the analysis includes the exploratory study on university autonomy (Estermann and Nokkala 2009) and Autonomy Scorecard (Estermann et al 2011). Those two research reports construct university autonomy as comprising four different dimensions, organisational autonomy, financial autonomy, staffing autonomy and academic autonomy, the status of which is compared through several further indicators accross 34 and 28 European countries respectively. The latter report (Estermann et al 2011) also rates and ranks European countries along these dimensions. The inclusion of certain autonomy dimensions and indicators and exclusion of others, although mandated by the practicalities of the research process also constitute the legitimate boundaries of discussing university autonomy, and the knowledge produced by the reports can be taken as a baseline when discussing the state of university autonomy in Europe ${ }^{2}$. Finally, the Magna Charta Universitatum (1988) signed by 776 universities worldwide, is referenced in the analysis, as its focus on autonomy is explicitly referred to in the EUA Salamanca Declaration (2001) as well as in the Bologna Declaration (1998).

The EUA documents are contrasted with the documents by the other significant actor and consultative member of the Bologna Process, namely the European Commission. Similarly, the analysis includes the Council of the European Union documents (EC 2003, 2005, 2006, 2011; Council of the European Union 2007, 2010), as well as communiqués of the ministerial meetings produced as part of the Bologna Process (Bologna Process 1999, 2001, 2003, 2005, 2007, 2009, 2010, 2012). Whilst the EUA documents and the Bologna Ministerial communiqués represent a complete sample, the European Union documents are limited to a set of recent documents which explicitly mention autonomy. Having introduced the theoretical and methodological framework based on theories of discursive framing and agenda setting, the paper will move on to recount the emergence of autonomy as a policy agenda in the European University Association. Secondly, it will offer an overview and a critical analysis of the uses and meanings of autonomy in EUA documents and juxtaposes these meanings with the construction of autonomy in the discourse of other actors.

\footnotetext{
2 “The Autonomy Scorecard is an exclusive benchmarking tool, which will help public authorities and higher education institutions to better assess university autonomy in the wider European framework, and thus promote the exchange of best practices in a rapidly evolving field.” www.eua.be
} 
Comparing these, it will aim to show how EUA used the discourse of autonomy in order to position itself in the Bologna Process. The concluding part will consider the implications of these results for further research on European higher education.

\section{The EUA discourse on autonomy}

The EUA discourse on autonomy revolves around three main themes. One relates to the definition of autonomy: this type of discourse seeks to define autonomy, its preconditions and limits. The second offers rationales or justifications for focusing on autonomy; in other words, it seeks to explain why autonomy is relevant for higher education in Europe. The third type is most explicitly concerned with agency, as it defines actors and institutions responsible for autonomy. Most of EUA policy documents feature all three types of discourse, sometimes emphasising a specific aspect.

\section{What is autonomy?}

Although some references to the definitions of autonomy can be found in earlier EUA documents, this theme mainly originates in the EUA's Lisbon Declaration in 2007, which laid down the four autonomy dimensions. These were taken as the basis for the EUA research on university autonomy (Estermann and Nokkala 2009; Estermann et al 2011). The exploratory study on university autonomy (Estermann \& Nokkala 2009, p. 6-7) defines the institutional autonomy in terms of the university's relationship with the state as "the constantly changing relations between the state and higher education institutions and the degree of control exerted by the state, depending on the national context and circumstances. The variety of situations across Europe reflects the multiple approaches to the on-going quest for a balance between autonomy and accountability in response to the demands of society and the changing understanding of public responsibility for higher education." The "multi-stage, interactive" study aimed to build a foundation for a comparative database in university autonomy across Europe, enabling universities and policy-makers to compare systems across borders and provide a voice for the European institutions to articulate what autonomy means in practise.

The follow-up study, Autonomy Scorecard, takes this one step further as it "aims to engage all relevant stakeholders in a more in-depth debate on autonomy and thereby help to improve higher education systems. It provides an institutional perspective on autonomy by involving the university sector, chiefly represented by the European national rectors' conferences, at all stages" (Estermann et al 2011, p. 8).

Through these reports the EUA has been able to insert into the European higher education discourse a powerful categorization to describe and define university autonomy from the perspective relevant to the organization and its constituencies. Each of the four dimensions: organisational, financial, staffing and academic autonomy, were elaborated with several further aspects, which vary somewhat across the two reports. 
Organisational autonomy covered issues such as internal academic and administrative structures, framework of decision-making structures, external members in governing bodies (and the university ability on deciding to include them and their appointment) the selection procedure and criteria of the executive head, procedures for the dismissal and the term of office of the executive head, the relations between the executive head and the governing bodies, and the university ability to create legal entities.

Financial autonomy was defined in terms of length of funding cycle and the type of modalities for public funding, intermediary funding bodies, audit procedures, ability to keep surplus on main public funding, to borrow money or raise it on financial market, to own and sell university buildings and to be able to charge tuition fees of national/EU and non-EU students at three degree levels.

Staffing autonomy was taken to include the capacity to decide on academic and/or administrative staff recruitment procedures and promotions, the ability to decide on overall salary costs and/or individual salary levels, the civil servant status of staff members, as well as the capacity to dismiss staff.

Finally, academic autonomy was discussed in terms of the university capacity to decide on its academic profile, overall numbers of students and numbers per discipline, student admission mechanisms and quotas, capacity to introduce and terminate degree programmes and to decide on their content, the capacity to choose the language of instruction, and to select appropriate quality assurance mechanisms and providers.

\section{Rationales: what is autonomy for?}

The case for autonomy in EUA documents is exercised through the construction of two main links. The first of these is the link between autonomy and competitiveness - we will call this autonomy-competitiveness nexus - which may be presented either as a lack of competitiveness in European higher education resulting from the lack of autonomy of the European higher education institutions (excerpt1), or the increased autonomy resulting in the increased competitiveness, which may remain unoperationalised, or as in this extract may be applied in the context of research performance (excerpt 2). Similarly, the valuable contribution of the European universities over the years has been attributed to autonomy.

The dynamics needed for the completion of the European Higher Education Area will remain unfulfilled or will result in unequal competition, if the current over-regulation and minute administrative and financial control of higher education in many countries is upheld. (EUA Salamanca Declaration 2001) 
Greater autonomy will provide universities with the necessary flexibility to respond to the challenges of diversifying their research and their funding missions in order to play more effectively their role in addressing society's needs and advancing Europe's competitiveness in the global economy. (EUA response to EC Green paper on ERA, 2007)

The second consistent link is between autonomy and accountability - the autonomyaccountability nexus - which functions as a way for the EUA to argue for more autonomy for the universities (excerpt 1 ) and as a way of persuading the external stakeholders that universities act responsibly (excerpt 2).

Progress requires that European universities be empowered to act in line with the guiding principle of autonomy with accountability. As autonomous and responsible legal, educational and social entities, they confirm their adhesion to the principles of the Magna Charta Universitatum of 1988 and, in particular, to that of academic freedom. (EUA Salamanca Declaration 2001)

Mission diversity, strategic capability, and accountability can only be developed if universities have the freedom to do this. The higher education system must therefore be based on autonomous institutions, with freedom to control and manage their own resources and to compete as well as collaborate, accepting the responsibility to make the most efficient use possible of the resources which they command; this requires that universities are trusted to act responsibly. (A vision and strategy for Europe's universities and the EUA 2006)

Autonomy-accountability nexus is also operationalised and applied in the context of quality assurance. This excerpt also shows how EUA is using its own knowledge production work to argue for its policy and how it uses the autonomy-accountability nexus in the quality context to shift the agency towards another institution, in this case the national rector's conferences.

EUA's concrete experience in quality, through the Quality Culture Project and the Institutional Evaluation Programme, has shown the inextricable link between institutional autonomy and accountability... The link between autonomy and internal quality is fundamental: the greater the institutional autonomy, the more robust are the internal quality processes. In this context, the national conferences of rectors must play an important role in negotiating with the national authorities and QA agencies the scope of the internal and external evaluations and of institutional autonomy. (EUA policy position on quality 2007) 
Another reoccurring feature is the linking of autonomy with the diversity of missions as in the excerpt 1 below. The same excerpt also indicates how the EUA seeks to fill the concept of autonomy with its own definition and make them part of the general discourse in the field. Autonomy as a concept is being operationalised and applied for example in the context of quality assurance, doctoral education, teaching and learning and research priorities. It may also be used as a passing reference to knowledge production in the field of autonomy, or in a purely "tokenistic" way, as in the excerpt 2 :

Governments are urged to endorse the principle of institutional autonomy so as to accommodate diverse institutional missions and to include academic autonomy (curricula, programmes and research) financial autonomy (lump sum budgeting), organisational autonomy (the structure of the university) and staffing autonomy (responsibility for recruitment, salaries and promotion). (EUA Lisbon Declaration 2007)

In order to fulfil these aspirations and to underpin cooperation in the different areas set out above, the EUA and CUIB reiterate the importance of strengthening the autonomy and responsibility of universities and of ensuring sustainable and diversified funding. (EUA Asturias declaration 2006)

\section{Who provides autonomy?}

The third aspect of autonomy discourse, and the one most directly connected to the question of agency, relates to the responsibility for autonomy - in other words, who is in charge of providing autonomy. Already in the 2001 EUA document, there is an indication that autonomy requires specific action on behalf of the state; more specifically, the states or governments are put in charge of "empowering" the universities. Thus, autonomy moves away from being an automatic consequence of the absence of external limitations, and towards an actively exercised condition that requires conscious action to enable it. In other words, from a negative definition - being free from something - it moves towards a positive definition - being free to do something.

This message appears not only in the Declarations, but also in the EUA studies on funding and autonomy. On the part of the EUA the autonomy as requiring extra measures represents a way for the EUA to convince its members of the tough stance of the EUA in advocating for the interests of its members. It is however, immediately combined with a call for the universities to do their bit, which then functions as a way to convince the other stakeholders of the reliability and realism of the organisation as an actor in the Bologna Process. 
Progress requires that European universities be empowered to act in line with the guiding principle of autonomy with accountability. (EUA Salamanca Declaration 2001)

Governments are urged to give universities the autonomy they need to introduce the agreed reforms.(EUA Glasgow Declaration 2005)

Empowerment, in this sense, seems to mean securing adequate funding and financial autonomy:

Autonomy should be founded on adequate public funding and should also facilitate the strategic management of public and private income and endowments (from philanthropists, companies, alumni and students) by the universities themselves. Governments are urged to benchmark progress against target levels set in relation to both autonomy and funding of universities. Universities will strive to reinforce further leadership and strengthen professional management. (EUA Lisbon Declaration 2007)

While universities need to be encouraged to develop in different forms and to generate funds from a variety of sources, governments must empower institutions and strengthen their essential autonomy by providing stable legal and funding environments thus ensuring that universities have the capability to manage themselves in a dynamic way and the freedom to act to seize the opportunities that are offered to them. (EUA statement on the research role of universities 2004)

The main agency in the context of autonomy, thus, is shifted from the state to the universities as institutions. At first, autonomy was framed as something that needs to be granted to the universities by the state. This framing has clearly been transformed into the emphasis on universities as "strong" institutions, which are now expected to take a more "proactive " role in acquiring and preserving autonomy.

Last, but not least, the Aarhus Declaration of 2011 further narrows down the responsibility for autonomy: from the university as an institution, to the university leadership:

Making European universities attractive for talented individuals and being able to offer them the appropriate career opportunities also requires strengthened autonomy. It is essential to ensure that university leaders are able to take the necessary decisions, especially in financial and staffing matters, to attract, remunerate, motivate and retain talented individuals at all levels. (EUA Aarhus Declaration 2011) 
The following part of the text will look at how these discourses are used to "agentify" or empower the EUA in the context of European higher education policy making, and how they were translated or appropriated in the policy documents of other actors.

\section{Autonomy discourse in the construction of EUA agency}

Drawing from Meyer and Jepperson's (2000) four features of agentic actors, we can see how EUA positions itself through the discourse of autonomy. This first function of the discourse, and the first feature of Meyer and Jepperson's (2000) typology, the agency for the self, refers to an actor, such as an organisation, establishing an organisational structure and goals to legitimate itself. Modern agentic actors involve themselves in all sorts of efforts to elaborate their agentic capabilities. In our case, university autonomy discourse presents one of the tools to establish the legitimated interests of the European University Association. It constructs itself as a rational, reliable and legitimate actor and stakeholder. The Autonomy Scorecard, in this sense, can be seen as a form of social technology (c.f. Rose 1996) through which an organisation takes control of the autonomy agenda, not just through policy declarations, but also through establishing "baseline" knowledge for the discussions of university autonomy.

The second function of the discourse and the second agentic feature, agency for other actors, refers to the capacity of the actor to "shift from agency for the self to agency for other actors, from actorhood to otherhood, whether these actors be states, organisations or individuals" (Meyer and Jepperson 2007, 107). In the case of EUA, these other actors are the constituent members of the EUA: individual universities and national rectors' conferences. The autonomy discourse is a strong tie between the EUA and its constituents: autonomy is not about the autonomy of the EUA itself, but of the organisations it represents.

The third agentic feature is the agency for non-actor entities, namely the tendency of actor to "mobilise as agents for the imagined interests of non-actor entities recognised in the cultural system" (Meyer and Jepperson 2000, 108). In the case of the autonomy discourse and the EUA, the global scientific community may be seen as such a non-actor entity. This feature is prominent especially in the earlier EUA documents of the where autonomy is presented as being crucial not only for the institutions in order to be able to fulfill their "missions", but for scientific community as well, as autonomy and academic freedom are equated in the discourse. This is true first and foremost in the Magna Charta Universitatum (1988) and in the Salamanca Declaration (2001) which explicitly reference it. Later on, the Bologna and EU documents make references to academic freedom, whilst the EUA documents don't.

This is closely related to the final agentic feature, agency for principle, which refers to the actor assuming "responsibility to act as an agent of the imagined natural and moral law", without which the "actor risks either incompetence or corruption" (Meyer and Jepperson 
$2000,108)$. In this feature, autonomy is constituted as the guarantor of quality, academic freedom and integrity of science; all manner of desirable characteristics and features such as funding stability and self-determination or the loftier political catchwords such as the "Europe of Knowledge". It thus represents the moral principle which is championed by the actor, giving it greater legitimacy. At the same time, it enables the EUA to use the autonomy-competitiveness nexus as a way to bargain for more autonomy.

\section{Convergence of discourses: successful agentification or hostile takeover?}

The analysis of the EUA discourse on autonomy shows how the definition, rationales, as well as responsibility for university autonomy were used to constitute EUA as the institution that, simultaneously, serves as an expert knowledge producer on the issues of autonomy (through studies and policy documents); represents the agendas and interests of its members (i.e. European universities) and thus acts on their behalf; and, last but not least, serves as the "arbiter" or authority on the general meaning of autonomy (e.g. through the Autonomy Scorecard). In this sense, from an association of universities and rectors' conferences that gave birth to EUA, the organisation has transformed into a centre of knowledge production that exercises a form of "monopoly" over the concept of autonomy and thus, consequently, over the political uses of the term.

How can we measure the degree of "success" of EUA in the construction of its own agency in the context of European higher education policy making? The first indicator is the extent to which EUA has managed to achieve representation in the decision-making bodies, especially those related to the Bologna Process. As noted in the beginning, in this sense EUA has indeed been recognised as the "voice of European universities". However, the presence of EUA in decision-making and policy fora does not, in and of itself, indicate that the organisation has been successful in asserting its definition of autonomy as a theoretical and political concept. In order to understand this aspect, we need to juxtapose EUA's discourses on autonomy with those of other actors in European higher education area. In other words, we need to see if there is conceptual "travel" of the meaning of autonomy from the EUA towards other actors. This section will thus compare the EUA discourses on autonomy with those of the European Commission, European Council and, not least, the Bologna Process itself.

The calls for financial autonomy and strong institutions, implicitly defined in terms of strong rectors or management, may indicate potential discursive coalitions (Hajer 1996) between the EUA and the European Commission. This would also indicate a successful agency building on part of the European University Association, as well as an ability to frame the policy agenda in a way that is consistent with their own goals. For instance, such 
convergence may be noted in the link between autonomy and competitiveness, in which the formulation from EUA's Salamanca Declaration:

The dynamics needed for the completion of the European Higher Education Area will remain unfulfilled or will result in unequal competition, if the current over-regulation and minute administrative and financial control of higher education in many countries is upheld.(EUA Salamanca Declaration 2001)

is echoed in the European Commission's The Role of Universities in the Europe of Knowledge:

However, the European university world is not trouble-free, and the European universities are not at present globally competitive with those of our major partners, even though they produce high quality scientific publications. The Communication notes a number of areas within which reflection, and often also action, is needed, and raises a series of questions such as:[...] how to ensure autonomy and professionalism in academic as well as managerial affairs; (EC 2003, p. 2)

Accountability is another element which appears in the autonomy discourse of all the actors. In the EUA discourse, accountability functions as a way of persuasion for the external stakeholders. Whilst the first extract below frames accountability as part of the notion of universities acting responsibly, the second one implicitly contrasts autonomy and accountability. One sub-definition of autonomy-accountability nexus, which can be seen both in the EUA Glasgow Declaration from 2005, and the Bologna Process Ministerial Communiqué from Berlin in 2003, is accountability determined specifically in terms of quality assurance, which has been one of the focal issues of the Bologna Process in general.

Progress requires that European universities be empowered to act in line with the guiding principle of autonomy with accountability. As autonomous and responsible legal, educational and social entities, they confirm their adhesion to the principles of the Magna Charta Universitatum of 1988 and, in particular, to that of academic freedom. (EUA Salamanca Declaration 2001)

Universities advocate a balance between autonomy and accountability through institutional audit procedures which: embody a fitness for purpose approach that is culturally adapted to countries and institutions and in line with their different missions and profiles; are aimed at strategic improvement and change rather than quality control; and are designed to develop a European dimension through European evaluation teams and to take into account engagement with society and commitment to the social dimension of the Bologna Process. (EUA Glasgow Declaration 2005) 
The European Commission discourse uses autonomy as a way to argue for universities to be broadly accountable to society, not just in terms of financial prudency or quality assurance, but in terms of producing wider benefit to the society:

Universities will not become innovative and responsive to change unless they are given real autonomy and accountability. Member States should guide the university sector as a whole through a framework of general rules, policy objectives, funding mechanisms and incentives for education, research and innovation activities. In return for being freed from overregulation and micro-management, universities should accept full institutional accountability to society at large for their results. This requires new internal governance systems based on strategic priorities and on professional management of human resources, investment and administrative procedures. It also requires universities to overcome their fragmentation into faculties, departments, laboratories and administrative units and to target their efforts collectively on institutional priorities for research, teaching and services. (EC 2006)

The EUA and the European Commission documents both introduced in 2005 a new element into the autonomy discourse, namely the link between autonomy and diversity. Whilst the European Commission discourse presents diversity as an additional issue, which together with autonomy will produce the desired effect of improving the competitiveness of the European higher education sector, for the EUA the diversity is a qualifier of autonomy, and represents an important message from its diverse membership base (see, for example the EUA Glasgow Declaration excerpt above).

Focusing on the strategic orientation of the whole system would allow the state to reinforce its public responsibility for higher education in the knowledge era-mainly by defining a regulatory framework within which strategic orientation combined with autonomy and diversity results in wider access and higher quality. (EC 2005, p7)

The notions of diversity and autonomy are repeated in the EUA Lisbon Declaration in 2007, and the European Commission report from 2011, indicating a further alignment between the discourses of the EUA and the European Commission.

Together accountability and diversity form defining limits for autonomy. It is unanimously acknowledged that there cannot be autonomy without accompanying accountability. At the same time, though, accountability measures, along with other elements of higher education policy must acknowledge and support the diversity of missions and forms of the higher education institutions, born of and strengthened by autonomy. 
Whilst the earlier Bologna Process Declarations and Communiqués put considerable emphasis on university autonomy (c.f. Bologna Declaration 1999; Berlin Communiqué 2003), in the later Communiqués, from 2009 and 2010, autonomy is only mentioned in passing, as if it had become taken for granted. Finally, in the 2012 Bucharest Communiqué, it indeed disappears from the discourse altogether, and is replaced by the concept of strong institutions, which seems to incorporate the option of autonomy, and figures as a functional equivalent of the autonomy concept of earlier times: the guarantor of competitiveness of the European higher education system.

The necessary ongoing reform of higher education systems and policies will continue to be firmly embedded in the European values of institutional autonomy, academic freedom and social equity and will require full participation of students and staff. (Leuven- Louvain-la-Neuve Declaration 2009)

We, the Ministers, recommit to academic freedom as well as autonomy and accountability of higher education institutions as principles of the European Higher Education Area and underline the role the higher education institutions play in fostering peaceful democratic societies and strengthening social cohesion. (Vienna Declaration 2010)

Higher education is an important part of the solution to our current difficulties. Strong and accountable higher education systems provide the foundations for thriving knowledge societies. Higher education should be at the heart of our efforts to overcome the crisis - now more than ever. (Bucharest Communiqué 2012)

\section{Conclusions}

The analysis in this paper emphasizes the multiple shifts that have taken place within the European University Association's autonomy discourse and in its relationship with the discourse of other actors in the field. The discourse on autonomy has shifted from a negative definition focusing on the lack of external constraints to a positive definition of enabling the universities to design and fulfil their mission, structures and procedures. At the same time, overall rationales have shifted from the protection of academic freedom, still very much emphasised in the Magna Charta Universitatum (1988, see also Zgaga 2010) to competitiveness, accountability and quality, which indicates also a shift in the relationship between higher education institutions, the state and society and the move of the universities from "ivory tower" to the "agora" (c.f. Nowotny et al 2001). Finally, EUA's discourse has travelled from the autonomy as "given" by the state to autonomy as "won" by universities and, more specifically, its leadership. Considering that the EUA is first and 
foremost an organisation of the university leadership, both in terms of its organisational and collective members, i.e. universities and national rectors' conferences, this shift seems logical. However, as we aimed to show, this discursive shift has not been unambiguous: it also meant that the concept of university autonomy began to converge with the more neoliberal concepts such as those promoted by the European Commission (c.f. Dale 2007).

In this context, it may make sense to ask whether the dilution and eventual disappearance of the autonomy concept in the newer European documents speaks of the victory or of the loss of the European University Association's attempt to set autonomy on the agenda of the European Higher Education Area. It may indicate that autonomy became codified in the discourse to the extent that it no longer requires attention. Or it may indicate that the autonomy discourse has served its purpose, competitiveness has become the established goal of the Bologna Process which no longer needs the boost and legitimation from the autonomy discourse. Secondly, while the European University Association has a strong and clear presence and representation structure in the Bologna Process, the representation of academic staff is organised through the Education International, which as a global organisanisation representing teaching in all levels of education is a very different kind of actor of the Bologna Process. Thus it may be that the European University Association's strong role in the Bologna Process has further contributed to the already discernible trend of defining the university essentially in terms of its leadership, rather than through the academic community (c.f. Taylor 2006).

In conclusion, we can say that the case of the discursive construction of agency through the concept of autonomy points to the need to frame the study of discourses and narratives surrounding the development of the European Higher Education Area in a more sociologically and politically grounded manner. This paper tried to demonstrate how the shifts in the discursive framing of autonomy in the texts produced by one specific policy actor - the European University Association - can be connected to the broader political dynamics of the Bologna process, including the struggle for monopoly over meaningmaking. As our analysis suggests, the outcomes of this struggle cannot be framed in terms of pure "success" or "failure", but rather in the extent to which it manages to define the agency of specific institutions and actors, and thus influences their power positions within the European higher education landscape. Analysing the mechanisms of agency construction is thus essential not only to the understanding of the current constellations of power and influence in the European Higher Education Area, but also to the empowerment of the other stakeholders of the Bologna Process.

\section{References}


Beerkens, E. (2008) The Emergence and Institutionalization of the European Higher Education and Research Area. European Journal of Education, 43(4), 407-25.

Benford, R. D., and Snow, D. A. (2000) Framing Processes and social movements: An overview and assessment. Annual Review of Sociology, 26, 611-639.

Bologna Process (1999) Bologna Declaration 1999. The European Higher Education Area. Joint Declaration of the European Ministers of Education. Convened in Bologna on the 19th of June 1999.

http://www.ehea.info/Uploads/Declarations/BOLOGNA DECLARATION1.pdf Retrieved 10.6.2014

Bologna Process (2001) Prague Communiqué 2001. Towards the European Higher Education Area. Communiqué of the meeting of European Ministers in charge of Higher Education in Prague on May 19th 2001.

http://www.ehea.info/Uploads/Declarations/PRAGUE COMMUNIQUÉ.pdf

Retrieved 10.6.2014

Bologna Process (2003) Berlin Communiqué 2003. Realising the European Higher Education Area. Communiqué of the Conference of Ministers responsible for Higher Education in Berlin on 19 September 2003.

http://www.ehea.info/Uploads/Declarations/Berlin Communiqué1.pdf Retrieved 10.6.2014

Bologna Process (2005) Bergen Communiqué 2005. The European Higher Education Area Achieving the Goals Communiqué of the Conference of European Ministers Responsible for Higher Education, Bergen, 19-20 May 2005.

http://www.ehea.info/Uploads/Declarations/Bergen Communiqué1.pdf Retrieved 10.6.2014

Bologna Process (2007) London Communiqué 2007. Towards the European Higher Education Area: responding to challenges in a globalised world. 18 May 2007.

http://www.ehea.info/Uploads/Declarations/London Communiqué18May2007.pdf

Retrieved 10.6.2014

Bologna Process (2009) Leuven/Louvain-la-Neuve Communiqué 2009. The Bologna Process 2020 - The European Higher Education Area in the new decade. Communiqué of the Conference of European Ministers Responsible for Higher Education, Leuven and Louvain-laNeuve, 28-29 April 2009. 
http://www.ehea.info/Uploads/Declarations/Leuven Louvain-la-

Neuve Communiqu\%C3\%A9 April 2009.pdf

Retrieved 10.6.2014

Bologna Process (2010) Budapest-Vienna Declaration on the European Higher Education Area. 12 March 2010.

http://www.ehea.info/Uploads/Declarations/Budapest-Vienna Declaration.pdf

Bologna Process (2012) Bucharest Communiqué 2012. Making the Most of Our Potential: Consolidating the European Higher Education Area. 26-27 April 2012.

http://www.ehea.info/Uploads/\%281\%29/Bucharest\%20Communiqué\%202012\%281\%29.p $\underline{\mathrm{df}}$

Retrieved 10.6.2014

Carayannis, E. G., \& Campbell, D. F. (2009) 'Mode 3'and'Quadruple Helix': toward a 21st century fractal innovation ecosystem. International Journal of Technology Management, 46(3), 201-234.

Corbett, A. (2005) Universities and the Europe of Knowledge. London: Palgrave Macmillan.

Council of the European Union (2007) Council resolution on modernising universities for Europe's competitiveness in a global knowledge economy - adoption of Council Resolution. 16096/1/07.

http://register.consilium.europa.eu/pdf/en/07/st16/st16096-re01.en07.pdf

Retrieved 10.6.2014

Council of the European Union (2010) Council conclusions of 11 May 2010 on the internationalisation of higher education. 2010/C 135/04.

http://eur-lex.europa.eu/LexUriServ/LexUriServ.do?uri=OJ:C:2010:135:0012:0014:EN:PDF

Retrieved 10.6.2014

Crosier, D.; Purser, L. \& Smidt, H. (2007) Trends V: Universities Shaping the European Higher Education Area. Brussels: EUA.

Dale, R. (2007). Changing Meanings of" the Europe of Knowledge" and" Modernizing the University," from Bologna to the" New Lisbon". European Education, 39(4), 27-42.

EC (2003) Communication from the Commission of 5 February 2003 - The role of the universities in the Europe of knowledge. $\operatorname{COM(2003)} 58$ final. 
http://eur-lex.europa.eu/legal-

content/EN/ALL/;jsessionid=k1h0TW6hV8KV8Y63jbjOLsvfGBMnpnYRy6wGbXbLZdvFWrMtChgC!1306

593838?uri=CELEX:52003DC0058

Retrieved 10.6.2014

EC (2005) Communication from the Commission of 20 April 2005 - Mobilising the brainpower of Europe: enabling universities to make their full contribution to the Lisbon Strategy. $\operatorname{COM}(2005) 152$ final.

http://eur-lex.europa.eu/LexUriServ/LexUriServ.do?uri=COM:2005:0152:FIN:EN:PDF

Retrieved 10.6.2014

EC (2006) Communication from the Commission to the Council and the European Parliament. Delivering on the Modernisation Agenda for Universities: Education, Research and Innovation. $\operatorname{COM(2006)} 208$ final.

http://eur-lex.europa.eu/LexUriServ/LexUriServ.do?uri=COM:2006:0208:FIN:EN:PDF

Retrieved 10.6.2014

EC (2011) Communication from the Commission to the European Parliament, the Council, the European Economic and Social Committee and the Committee of the Regions. Supporting growth and jobs - an agenda for the modernisation of Europe's higher education systems. $\operatorname{COM(2011)} 567$ final.

http://ec.europa.eu/education/library/policy/modernisation en.pdf

Retrieved 10.6.2014

Elken, M., \& Vukasovic, M. (2014) Dynamics of voluntary coordination: actors and networks in the Bologna Process. In: Chou, M. H., \& Gornitzka, A. (Eds). Building the Knowledge Economy in Europe: New Constellations in European Research and Higher Education Governance. Cheltenham: Edward Elgar Publishing.

Estermann, T. \& Bennetot Pruvot, E. (2011) Financially Sustainable Universities II: European universities diversifying income streams. Brussels: EUA.

Estermann, T. \& Nokkala, T. (2009) University Autonomy in Europe I. Exploratory study. Brussels: EUA.

Estermann, T.; Nokkala, T. \& Steinel, M. (2011) University Autonomy in Europe II. The Scorecard. Brussels: EUA

EUA (2000) Merger agreement between the Association of European Universities (CRE), and the Confederation of European Union Rectors' Conferences. Draft. 
http://www.eua.be/eua/jsp/en/upload/Merger Report of Joint task group.10687989507 90.pdf

Retrieved 10.6.2014

EUA (2001) Salamanca Declaration. The Bologna Process and the European Higher Education Area. Brussels: EUA.

http://www.eua.be/eua/jsp/en/upload/SALAMANCA final.1069342668187.pdf

Retrieved 10.6.2014

EUA (2003) Graz Declaration. Forward from Berlin: the role of universities. Brussels: EUA http://www.eua.be/eua/jsp/en/upload/COM PUB Graz publication final.1069326105539. pdf

Retrieved 10.6.2014

EUA (2004) EUA Statement on the Research Role of Europe's Universities. Brussels: EUA. http://www.eua.be/typo3conf/ext/bzb securelink/pushFile.php?cuid=2122\&file=fileadmin/user up load/files/EUA1 documents/EUA Research Liege conf 23042004.pdf

EUA (2005) Glasgow Declaration. Strong Universities for a Strong Europe. Brussels: EUA http://www.eua.be/eua/jsp/en/upload/Glasgow Declaration.1114612714258.pdf Retrieved 10.6.2014

EUA (2006) A vision and strategy for Europe's universities and the European University Association. Brussels: EUA.

http://www.eua.be/typo3conf/ext/bzb securelink/pushFile.php?cuid=2122\&file=fileadmin/ user upload/files/EUA1 documents/EUA Vision strategy universities.pdf

Retrieved 10.6.2014

EUA (2006) Asturias Declaration. Brussels: EUA.

http://www.eua.be/typo3conf/ext/bzb_securelink/pushFile.php?cuid=2122\&file=fileadmin/ user upload/files/EUA1 documents/EUA CUIB Asturias Declaration 210406.pdf Retrieved 10.6.2014

EUA (2007) Lisbon Declaration. Europe's Universities beyond 2010: Diversity with a Common Purpose. Brussels: EUA

http://www.eua.be/eua-work-and-policy-area/eua-policy-position-and-Declarations.aspx Retrieved 10.6.2014

EUA (2007) European Commission's "Green Paper" on "The European Research Area: 
New Perspectives". Viewpoint from the European University Association (EUA). Brussels: EUA.

http://www.eua.be/typo3conf/ext/bzb securelink/pushFile.php?cuid=2122\&file=fileadmin/ user upload/files/Policy Positions/EUA Response to ERA Green Paper.pdf

Retrieved 10.6.2014

EUA (2007) EUA policy position on Quality. Brussels: EUA.

http://www.eua.be/typo3conf/ext/bzb securelink/pushFile.php?cuid=2122\&file=fileadmin/ user upload/files/EUA1 documents/EUA policy position quality.pdf

Retrieved 10.6.2014

EUA (2009) Prague Declaration. European Universities: Looking forward with confidence. Brussels: EUA

http://www.eua.be/eua-work-and-policy-area/eua-policy-position-and-Declarations.aspx Retrieved 10.6.2014

EUA (2011) Aarhus Declaration. Investing Today in Talent for Tomorrow. Brussels: EUA. http://www.eua.be/Libraries/Policy Positions/Aarhus Declaration 2011.sflb.ashx

Retrieved 10.6.2014

Foucault, M. (1980) Power/knowledge: Selected interviews and other writings, 1972-1977.

Edited by Colin Gordon. Hemel Hempstead: Harvester Wheatsheaf.

Greenwood, J. (2007a) Review Article: Organized Civil Society and Democratic Legitimacy in the European Union. British Journal of Political Science, 37(2), 333-357.

Greenwood, J. (2007b) Interest representation in the European Union. Basingstoke : Palgrave Macmillan.

Hajer, M. (1996) Ecological modernisation as cultural politics. In: Lash, S.; Szerszynski \& Wynne, B. (Eds). Risk, environment \& modernity: Towards a new ecology. London: Sage Publications.

Haug, G. \& Kirstein, J. (1999) Trends in Learning Structures in Higher Education. Project Report. http://www.eua.be/eua/jsp/en/upload/OFFDOC BP trend I.1068715136182.pdf Retrieved 10.6.2014

Haug, G. \& Tauch, C. (2001) Trends II. Towards the European Higher Education Area : survey of main reforms from Bologna to Prague. Summary and conclusions. Brussels: EUA 
Hoppe, R. (1993) Political Judgement and the Policy Cycle: The Case of Ethnicity Policy Arguments in the Netherlands. In: Fischer, F. \& Forester, J. (Eds) The Argumentative Turn in Policy Analysis and Planning. Durhan, NC: Dukes University Press.

Jessop, B. (2004) Critical semiotic analysis and cultural political economy. Critical discourse studies, 1(2), 159-174.

Jørgensen M. \& Phillips, L. (2002) Discourse Analysis as Theory and Method. London: Sage Publications.

Keeling, R. (2006) The Bologna Process and the Lisbon research agenda: the European Commission's expanding role in higher education discourse. European Journal of Education 41(2), 203-223.

Klemenčič, M. (2011) Europeanisation of the "European Student Movement". Paper presented at EUSA Twelfth Biennial International Conference Boston, Massachusetts, March 3-5, 2011. http://euce.org/eusa/2011/papers/7c klemencic.pdf

Retrieved 10.6.2014

Krzyzanowski, M. (2010) Discourses and Concepts: Interfaces and Synergies between Begriffsgeschichte and the Discourse Historical Approach in CDA. In : De Cillia, R., Gruber, H., Krzyzanowski, M., \& Menz, F. (Eds). Diskurs, Politik, Identität/ Discourse, Politics, Identity, Tübingen: Stauffenburg Verlag.

Krzyzanowski, M. \& Wodak, R. (2011) Political strategies and language policies; the European Union Lisbon strategy and its implications for the EU's language and multilingualism policy. Language Policy,10(2), 115-136.

Kogan, M. (2007) Modes of Knowledge and Patterns of Power. In: Sorlin, S. \& Vessuri, H (Eds) Knowlede Society vs. Knowledge Economy: Knowledge, Power and Politics. London: Routledge.

Kuhn, T. (1962) The structure of scientific revolution. Chicago: University of Chicago Press.

Loukkola, T. \& Zhang, T. (2010) Examining Quality Culture: Part 1 - Quality Assurance Processes in Higher Education Institutions. Brussels: EUA.

Magna Charta Universitatum (1988). Bologna 18th September 1988. http://www.magna-charta.org/library/userfiles/file/mc english.pdf Retrieved 10.6.2014 
Meyer, J. W. \& Jepperson, R. L. (2000) The 'Actors' of Modern Society: The Cultural Construction of Social Agency. Sociological Theory, 18(1), 100-120.

Newman, J. (2001) Modernising Governance. New Labour, Policy and Society. London: Sage Publications.

Nokkala, T. \& Bladh, A. (2014) Institutional Autonomy and Academic Freedom in the Nordic Context-Similarities and Differences. Higher Education Policy 27(1), 1-27.

Nowotny, H.; Scott, P. \& Gibbons, M. (2001) Rethinking science: knowledge in an age of uncertainty. Cambridge: Polity

Parker, I. (1992) Discourse dynamics. Critical analysis for social and individual psychology. London: Routledge.

Ravinet, P. (2008) From voluntary participation to monitored coordination: why European countries feel increasingly bound by their commitment to the Bologna Process. European Journal of Education, 43(3), 353-367.

Reichert, S. (2009) Institutional Diversity in European Higher Education: Tensions and Challenges for Policy Makers and Institutional Leaders. Brussels: EUA

Reichert, S. \& Tauch, C. (2003) Trends 2003. Progress towards the European Higher Education Area Bologna four years after: Steps toward sustainable reform of higher education in Europe. Brussels: EUA

Reichert, S. \& Tauch, C. (2005) Trends IV: European Universities Implementing Bologna. Brussels: EUA.

Robertson, S. \& Keeling, R. (2008) Stirring the Lions: Strategy and Tactics in Global Higher Education. Globalisation, Societies and Education 6(3), 221-40.

Rose, N. (1996) Governing "Advanced" liberal democracies. In Barry, A.; Osborne, T. \& Rose, N. (Eds) Foucault and Political Reason. Liberalism, neo-liberalism and rationalities of government. London: UCL Press.

Schmidt, V.A. (2002) Does Discourse matter in the politics of welfare state adjustment? Comparative Political Studies, 35(2), 168-193. 
Sell, S. \&Prakash, A. (2004) Using Ideas Strategically: The Contest Between Business and NGO Networks in Intellectual Property Rights. International Studies Quarterly, 48(1),143175.

Shin, H. J. \&Tsutsui, K. (2007) Constructing Social Movement Actorhood: Resident Koreans' Activism in Japan since 1945. International Journal of Comparative Sociology, 48(4), 317-35.

Snow, D.A.; Rochford, E.B.; Worden, S.K. \& Benford, R.D.(1986) Frame alignment Processes, micromobilization, and movement participation. American Sociological Review, 51(1), 6481.

Sursock, A. (2011) Examining Quality Culture Part II: Processes and Tools - Participation, Ownership and Bureaucracy. Brussels: EUA

Sursock, A. \& Smidt, H. (2010) Trends 2010: a decade of change in European Higher Education. Brussels: EUA

Taylor, J. (2006) "Big is beautiful." Organisational change in universities in the United Kingdom: New models of institutional management and the changing role of academic staff. Higher Education in Europe, 31(3), 251-273.

Voegtle, E.; Knill, C.\& Dobbins, M. (2011) To what extent does transnational communication drive cross-national policy convergence? The impact of the bologna-process on domestic higher education policies. Higher Education, 61(1), 77-94.

Wodak, R. (2001) The discourse - historical approach. In: Wodak, R. \& Mayer, M. (Eds),S Methods of Critical Discourse Analysis. London: Sage Publishers.

Wodak, R. (2008) Introduction: Discourse Studies - Important Concepts and Terms. In R. Wodak R. \& Krzyzanowski, M.(Eds), Qualitative Discourse Analysis in the Social Sciences. Basingstoke: Palgrave Macmillan.

Wright, S. (1998) The Politicization of 'Culture'. Anthropology Today, 14(1), 7-15.

Zgaga, P. (2010) The Development of a Standard-Setting Instrument on Academic Freedom and Institutional Autonomy: the Role of Public Authorities. Feasibility study for the Steering Committee for Higher Education and Research, Council of Europe. Ljubljana: Centre for Education Policy Studies.

http://ceps.pef.uni-lj.si/images/stories/projekti/int/doc/2010\%20Autonomy E.pdf

Retrieved 10.6.2014 